\title{
Agroforestry: An effective multi-dimensional mechanism for achieving Sustainable Development Goals
}

\author{
Laxmi Goparaju ${ }^{1 *}$, Firoz Ahmad ${ }^{1}$, Meraj Uddin ${ }^{2}$ Javed Rizvi $^{3}$ \\ ${ }^{1}$ Vindhyan Ecology and Natural History Foundation, Mirzapur, Uttar Pradesh, India, \\ ${ }^{2}$ University Department of Mathematics, MCA, Ranchi University, Ranchi, \\ Jharkhand, India \\ ${ }^{3}$ World Agroforestry (ICRAF), South Asia Regional Program, New Delhi, India \\ *corresponding author e-mail: goparajulaxmi @yahoo.com
}

Received: 14 December 2019 / Accepted: 23 April 2020

\begin{abstract}
The ecological footprint has far surpassed the biocapacity of our globe to fulfill the current requirement of the people living on the earth which needs sustainable vision with synergic alternative/option to meet the current human demand without compromising the need for the future generation.

We examined the various SDGs goals with respect to agroforestry capacity and contribution based on available literature and knowledge. The study provides a better understanding of the synergic approach/strategies with retrospective and prospective ways for choosing agroforestry exercise which is an effective mechanism for providing multi-dimensional ecosystem services without interruption in achieving the majority of SDGs goals.

The outcome of the evaluation highlights that agroforestry can contribute very significantly and can play a vital role in SDG-1, SDG-2, SDG-11, SDG-13, and SDG-15 directly in mitigating poverty, contributing towards food security, improving in creating a viable healthy city and in providing a sustainable overall prosperous environment in the prevailing climate change setup whereas indirectly it can serve others SDGs goals simultaneously that aim to provide better health and education, women empowerment, effective contribution towards clean water and energy for all sections of the society/citizen.

The analysis further concluded although agroforestry has a vibrant future and hope it will get adequate priority in various countries with a focus on policy and investment.
\end{abstract}

Keywords: agroforestry, trees, priorities, agroforestry policy, Sustainable Development Goals.

\section{Introduction}

The ecological footprint in term of demand has far surpassed the bio-capacity of our globe which need 1.5 earths to fulfill the current requirement of the people living on earth on nature (Singh, 2017) whereas world scientists believe up to 2050 the disastrous situation will arise because of increasing use but diminishing resources (Holloway, 2012). The decision needs to be taken for the future to get some early insights/visions into what alternative/option we have today for sustainable development (Fulton, 2013). The Brundtland Commission defined sustainable development as "meeting current human demand without compromising the needs of future generation" (WCED, 1987). The aim of the present work here is to examine the various SDGs goals with respect to agroforestry capacity and contribution based on available literature and knowledge. 


\section{Agroforestry for achieving sustainability}

The significance of agroforestry (AGF) based land use management practices were well identified in the year 1970 onwards seeing its potentiality from farm to the forest due to alarming food situation in a large swath of the developing world, continuous increasing deforestation trend of tropics and degrading ecological status, and inclination in multi-dimensional farming practices by scientific community/ World Bank/ FAO (Nair, 1993). Agriculture profession alone eventually is not relatively encouraging due to commonly inexpedient price regime and insignificant value/worth addition, leading towards quieting of farming practices and moving for migration from rural sectors which demand the policy focus towards the agrarian community to motivate them for AGF practices for better income by new technology, expansion, and financial support delivery mechanism and eliminating the barriers for facilitating the AGF setup (Prasad, 2002).

The World Agroforestry (ICRAF) has the supremacy to the AGF policy initiative at the national and local level with major goals of reforms across relevant sectors that reduce barriers and improve incentives for private investment and in enabling service provision in AGF considering the major benefits such as climate change adaptation/ mitigation tools, more efficiently integration/participation of governance institution/resources, to reach the needs of smallholders/ groups who are poor, marginalized, and most vulnerable farmers and society (ICRAF, 2010). Nepal has become 2 nd nation in the world which launched its national agroforestry policy after India during July 2019 by continuous governmental/institutional level discussion by ICRAF seeing its potentiality in improving livelihoods and increase in their resilience to climate change towards poor farming communities (Finlayson, 2019) which will serve some of the important major goals of SDGs.

Forests, Trees, and Agroforestry (FTA) is the world's largest research carried out by the CGIAR Research Program to magnify the role of forests, trees, and AGF in sustainable development and food security and to address the climate change. CGIAR (2016) report studied some of the issues such as gender research to involve the active participation of women and marginalized groups in the forest vicinity of Nepal, India, Nicaragua, and Uganda. The result highlights the increase in women's confidence, participation in community forestry, and opportunities to benefit from trees. Additionally, the report highlights the capacity building in terms of policy and practice support tools in REDD + Knowledge Tree, REDD + Cost Model, and guidelines to increase the participation of marginalized ethnic minorities in agricultural research/ development.

Garrity (2004) examined the AGF research and development (R\&D) linkage to the Millennium Development
Goals (MDGs). The study highlights the path in which AGF is substantively supporting to achieve the goals and analyze how the agenda can be transformed to further increase its capacity to meet the MDG targets. Furthermore, he highlighted how AGF mechanisms work to magnify on-farm food production and enhance income which contributes to the number of hungry and desperately poor people. Finally, he concluded that the agroforestry R\&D is contributing virtually to all the eight MDGs, therefore the national agroforestry strategies should be recognized and put forward as the main framework especially more in developing countries.

The Sustainable Development Goals (SDGs) are the blueprint for transforming our world towards sustainability which was adopted by all United Nations Member States in 2015 to build on progress made toward the eight Millennium Development Goals with emergent challenges such as action to end poverty, climate change, economic, inequality, innovation, sustainable consumption, and justice to ensure that all people enjoy peace and prosperity by 2030 . There are 17 Sustainable Development Goals described in Figure1. Trees in various setups in villages, cities and countries can meet 15 of the 17 SDGs goals because of interlinking benefits (Turner-Skoff \& Cavender, 2019). Over $50 \%$ of the targets out of 169 fixed in Sustainable Development Goals are directly related to the environment (Singh, 2017).

Sustainable Development Goals (SDGs) interacts significantly with agriculture and forestry jointly thus there is a need to integrated land use management (forests, trees, and agricultural practices) a technology alternative for uninterrupted sustainable 'ecosystem services' which demand separate policy domain for agroforestry for achieving the SDGs objectives by orienting higher levels of integration of financial and human resources within the existing frameworks when combined from national/ global to local development planning (von Noordwijk et al., 2018).

ICRAF since creation from 1970 onwards in conjugation with his partners have magnified agroforestry research and development activities around the globe in various domain, based on their experience and they can contribute directly to SDGs 1-3 (for eliminating poverty, hunger and the betterment of citizen for wellbeing and good health), SDGs 6-8 (for providing clean water, energy, sanitation and satisfactory economic growth), SDGs 11-13, 15 (for sustainable cities for people with responsible consumption and production including adequate strategy and plan in climate change scenario for enhancing unending life on land), and indirectly through implementation mechanism to Goals 4-5 (quality education with gender equality), Goals 9 (industry, innovation, and infrastructure), Goals 10 (reduced inequalities), Goals 14 (life below water), Goals 16 (peace, justice, and strong institutions) and Goals 17 (partnerships for the goals) (ICRAF, 2016). 


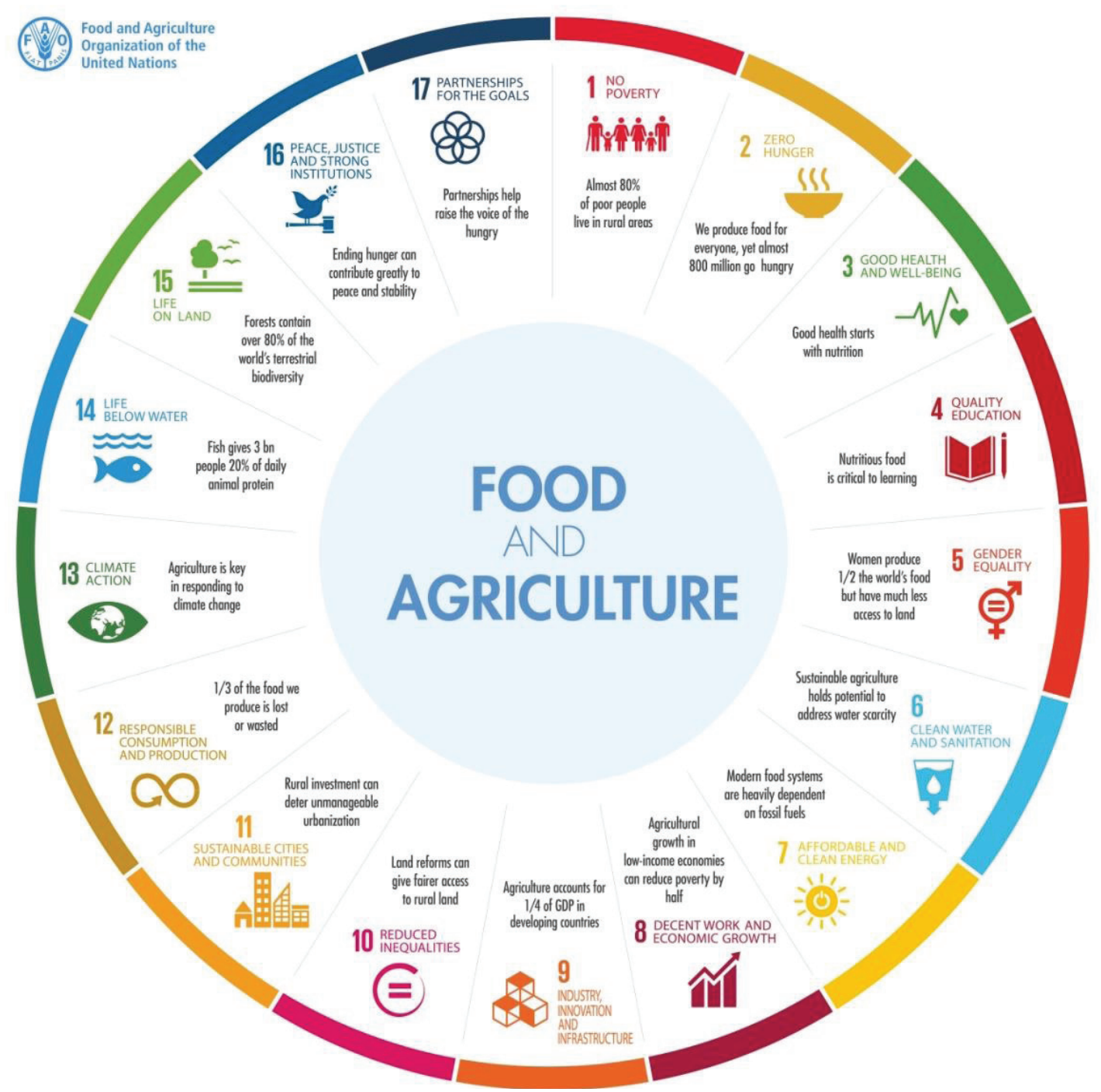

Figure 1. Sustainable Development Goals as an Infographic. Source: http://www.fao.org/fileadmin/user_upload/ codexalimentarius/photo-archive/Infographics/SDG-Wheel.jpg

Poverty is a condition in which a person or community can't be met with basic human needs essentials for a minimum standard of living which is a curse for a civilized society. Rural poverty is more severe while comparing it with urban areas. Approximately four-fifth world's extreme poor globally reside in rural areas (Castaneda et al., 2018) majority are found in developing countries, with diminishing livelihood/ poor agriculture sector performance and inadequate infrastructure/ market facility. AGF being most multifunctional forms of agriculture and have a greater role in improving the rural livelihoods (FAO, 2004), also the most appropriate tool to eliminate rural poverty if implemented in a suitable environment with adequate design from local to the national level (Ahmad \& Goparaju, 2017; FAO, 2018a). The study by Leakey et al. (2005) in many villages of Cameroon and Nigeria highlights some indigenous knowledge of farmers of Agroforestry Tree Products (AFTPs) incorporated in farming systems have given very positive results which will certainly enhance the livelihoods for poor farmers in the tropics if policy guidelines have been developed in support of this sustainable rural development strategies. Such strategies will work in eradicating poverty and hunger, promoting social equity and environmental sustainability (Leakey et al., 2005).

Scientific research now clearly reported that the adoption of AGF can increase yields/farm output significantly and end hunger along with improve nutrition, achieve food security towards SDG-2 goal (Montagnini \& Metzel, 2017) depends on local conditions, level of skill utilized, crop types/diversity (Garrity et al., 2010; Pretty \& Bharucha, 
2014; Pretty et al., 2003; Waldron et. al., 2015) and can reduce poverty (SDG-1) by enhancing the income several fold (Gangadharappa et al., 2003), provide multiple ecosystem services such as magnify soil nutrient by nitrogen fixation tree species, reduced crop stress (through reduced temperature and rainfall extremes), reduced soil erosion (root soil binding capacity), and administrate the water balance by uplifting of deep water by tree roots (Garrity et al., 2010; Leakey, 2014; Pretty et al., 2003; Waldron et al., 2015), reduce crop pest and disease by adopting crop rotation strategies (Schroth et al., 2000), restore/regenerate degraded fallow lands (Garrity et al., 2010; Leakey, 2014) and work as climate change mitigation strategies (Kumar et al., 2012; Mbow et al., 2014). Additionally, SDG-2 cannot be achieved without adequate female participation/engagement (SDG-5) because their access to knowledge of agriculture and nutrition is vital (GFRAS, 2015). Furthermore, SDG 1-2 cannot be achieved without resilience to climate change (SDG-13) because of the shocks such as weather and climate severity: floods, droughts, soil moisture deficit; input cost: for seeds, fertilizer, irrigation and pesticide and adequate market price: for farm output commodities will further push the system towards hunger and poverty (Waldron et. al., 2017). Additionally, achieving the SDG-13 goal is important because the earth's temperature is going to be increased to $3-5^{\circ} \mathrm{C}$ by 2100 due to GHGs increasing trend highlighted in one of the reports of the UN World Meteorological Organization (Reuters, 2018). Global warming and its impacts on agriculture with the associated environment make the path for the climate-smart agriculture (CSA) approach (Lipper et al., 2014) towards SDGs in new climate change reality (FAO, 2019). Various studies highlight environmental degradation will certainly impact the fulfillment of the objectives of SDGs 14 (Arora \& Mishra, 2019).

AGF reduces pressure from a natural forest of fuel, fodder and wood collection by generating diversified output on-farm habitats outside protected land can play an important role in biodiversity conservation/ ecosystem services (SDG15) in human-dominated landscapes and fill the gap of fragmentation from nature reserves (Schroth et al., 2004; Swallow et al., 2005; Bhagwat et al., 2008; Clough et al., 2011; Tscharntke et al., 2011; AN, 2018; Waldron et al., 2017).

Two-thirds of the world population at least a part of the year faces severe water scarcity (Mekonnen \& Hoekstra, 2016). Water crisis leads to poverty of around one-third of the world's people and thus important for achieving SDG6. Water crisis characterized by groundwater depletion, rivers pollution, and misuse of drinking water is very significant in the majority of developing countries. The report by WHO/UNICEF Joint Monitoring Programme (JMP) revealed the 785 million people lack access to a basic drinking water source and approximately 2 billion people lack access to a toilet which needs adequate compulsion to SDG-6 is dedicated to clean water and sanitation (https:// water.org/financingsdg6/). Trees act as water catchment by simply reducing surface flow so that water gets enough time to penetrate deeper into the soil thereby raising the water table and regulate soil water dynamics by infiltration, percolation, storage, and water use (i.e. transpiration/ evaporation) (Negri, 2018). The AGF in terms of tree presence in agricultural fields enhances infiltration capacity manyfold (Ilstedt et al., 2007). The magnified infiltrations through the tree root system reduce runoff and soil loss (Anderson et al., 2009). The study in West Africa by Ilstedt et al. (2016) highlights the intermediate tree densities that maximized groundwater recharge (Langford, 2016).

The world urban population increased five times from 746 million between the periods 1950 to 2015 whereas up to the year 2050 the urban populations in low and middleincome countries projected to grow more than double and triple (United Nations, 2016). The rapid increase of urban population threatening the urban sustainability in term of the alarming increase of air/sound pollution, decrease in the fresh air, urban heat island and deteriorating living conditions (such as sanitation, fresh drinking water, and shelter) in urban sprawl which threatening the human health and wellbeing (SDG 3). Tree improves health such as from stress (Jiang et al., 2015), cardiac-related issues (Kardan et al., 2015), neurodegenerative disease (Mooney $\&$ Nicell, 1992) and physical and mental condition (Bell et al., 2008; Ellaway et al., 2005)

Therefore it is important, to promote/magnify the safe, inclusive, accessible and green public spaces (SDG 11) for urban inhabitant which will also facilitate the multifunctional designed area for social interaction and inclusion (SDGs 10 and 11) and magnify the economic exchange, cultural expression, and dialogue among a wide diversity of people and cultures (SDG 8) which ensures mandatory human development and build peaceful, inclusive and participatory societies (SDGs 10 and 16) (FAO, 2018b).

Urban forestry in the city plays a significant role (benefits are given in Figure 1: Ahmad \& Goparaju, 2016) because it reduces air pollution (Nowak et al., 2010), mitigate the intensity of heat by cooling through evapotranspiration (Akbari et al., 1997; Shashua-Bar et al., 2009), reduces noise pollution (Fang \& Ling, 2005), mitigate the stormwater runoff (Fazio, 2010), improves the air (by reducing carbon dioxide and adding oxygen) (Escobedo et al., 2010), maintains the biodiversity (Khera et al., 2009) which overall maintain the quality of life and healthy environment for urban inhabitants which need a well-defined framework (Lawrence et al., 2013) with adequate green space for the city for ensuring the sustainable urban development. The urban green space in the city should not be less than $9 \mathrm{~m}^{2}$ per inhabitant is recommended by the World Health Organization (WHO, 2010; Morar et al., 2014). The urban green 
space $\mathrm{m}^{2}$ per inhabitant in developed countries is significantly high (France, 80 (Moigneu, 2001), Netherlands, 228 (Konijnendijk, 2003), Australia, 80 (Brack, 2002), Europe, 104 (Konijnendijk, 2003)) whereas it is significantly low in cities of developing countries (Maryanti et al., 2016) except few well-planned cities (Ahmad \& Goparaju, 2016).

The trees in terms of green space need to be magnified several folds in cities as per the open space availability and land potentiality in form of park/garden, aquaculture, roadside and community plantation, etc. (Ahmad \& Goparaju, 2016) should be extended more towards suburban zones (because of unavailability of open space at city Centre) to achieve SDG-11 with meaningful involvement of inhabitant as people participation and awareness approach. Furthermore, the effective wastewater treatment (SDG-6) is lacking in developing countries for the use of treated wastewater for the greening of landscapes into urban and semi-urban areas should be used immediately in the downstream landscape which will also help city dwellers in the production of goods and environmental services (FAO, 2016).

We have evaluated articles/case studies/expert opinions to understand the AGF role in terms of percent contribution and capacity for achieving various SDGs goals as a virtual illustration is given in Figure 2. The method we have adopted were investigated based on available literature resources which were calculated in term of percent contribution and the agroforestry capacity was determined based on expert opinion purely based on their scientific knowledge.

From this Figure 2, it is clear the role of AGF contribution in terms of its percent (redline) and agroforestry capacity (shade of color) are highly appropriate strategies for achieving SDG-1, SDG-2 SDG-11, SDG-13 and SDG-15 goals directly in abolishing poverty, contributing towards

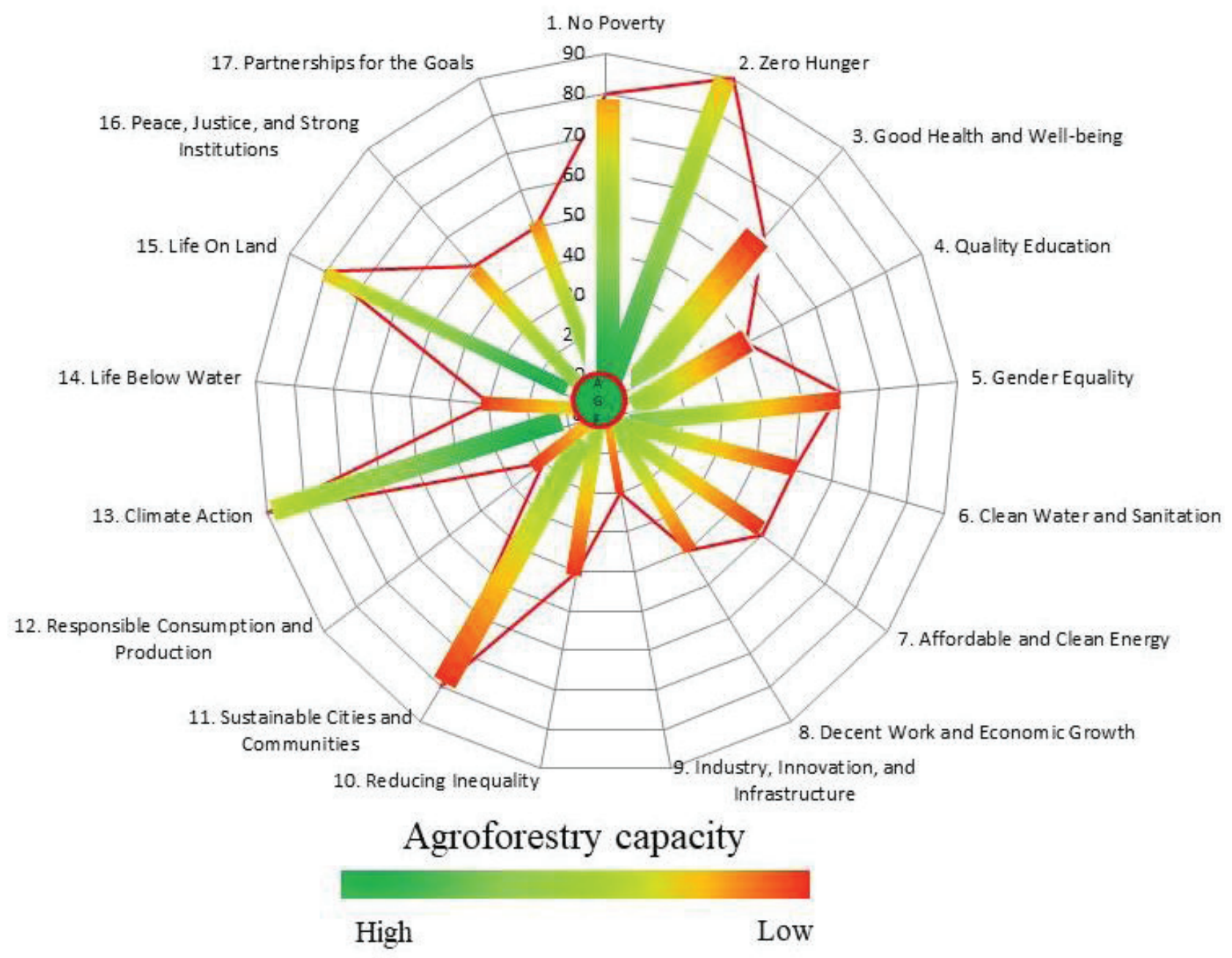

Figure 2. AGF capacity (shade of color from green to red: high to low) and approximate percent contribution (red line) for achieving different SDG goals compiled by authors 
food security, improving in creating a viable healthy city and in providing a sustainable overall prosperous environment in the prevailing climate change setup whereas indirectly it can serve several others SDGs goals (because of their complex linkage) simultaneously that aim to provide better health and education, women empowerment, effective contribution towards clean water and energy, capacitybuilding and improving the effectiveness and accountability for all section of society/citizen.

The AGF priority for achieving SDG goals significantly varies geographically which needs an appropriate prior evaluation of land, soil, topography, climate, and socioeconomic potentiality/suitability for AGF setup and then scaling/magnifying it for local/regional/national levels (Ahmad et al., 2019). More than 130 countries have shown their interest through national development plans to show their priorities for achieving SDGs (Chimhowu et al., 2019) and hope agroforestry will get sufficient space in their priorities with adequate policy attention and investment to fulfill its potential (Tsioumani, 2018).

\section{Conclusions}

This study highlights several SDGs goals that can be achieved using AGF if it is implemented with fair priority allowing adequate policy intervention. Some reports highlight the major SDG 15 (life on earth) goal is lagging in priority ranking (SDG report, 2019) whereas the main environmental goals are showing the slowest progress (Sachs et al., 2019; Arora \& Mishra, 2019). The knowledge gap and its management in each SDGs goal are important aspect from local to higher level need to be enhanced which will improve SDGs achievable capability (Barrantes \& Santos, 2019). Although there are high numbers of studies available on agroforestry research, still more in-depth studies of the agroforestry knowledge database are required to reveal its complex spatial relationship with land, environment, and community which will serve more meaningfully in achieving the SDGs goals in future.

\section{References}

Ahmad F. \& Goparaju L., 2017, Land evaluation in terms of agroforestry suitability, an approach to improve livelihood and reduce poverty: a FAO based methodology a geospatial solution: a case study of Palamu district, Jharkhand, India. Ecological Questions 25: 67-84. https://doi.org/10.12775/EQ.2017.006.

Ahmad F. \& Goparaju L., 2016, Geospatial Technology in Urban Forest suitability: Analysis for Ranchi, Jharkhand, India. Ecological Questions 24: 45-58.
Ahmad F., Uddin M.M. \& Goparaju L., 2019, Agroforestry suitability mapping of India: geospatial approach based on FAO guidelines. Agroforestry Systems 93: 13191336. https://doi.org/10.1007/s10457-018-0233-7.

Akbari H., Kurn D.M., Bretz S.E. \& Hanford J.W., 1997, Peak power and cooling energy savings of shade trees. Energy and Buildings 25: 139-148.

AN, 2018, AGROFORESTRY NETWORK (AN): Achieving the Global Goals through agroforestry. https:// www.siani.se/wp-content/uploads/2018/09/chievingTheGlobalGoalsThroughAgroforestry_FINAL_ WEB_144ppi-1.pdf

Anderson S.H., Udawatta R.P., Seobi T. \& Garrett H.E., 2009 , Soil water content and infiltration in agroforestry buffer strips. Agroforestry Systems 75: 5-16.

Arora N.K. \& Mishra I., 2019, United Nations Sustainable Development Goals 2030 and environmental sustainability: race against time. Environmental Sustainability 2: 339-342. doi:10.1007/s42398-019-00092-y.

Barrantes C. \& Santos F., 2019, Knowledge management, the missing piece in the 2030 agenda and SDGs puzzle. International Journal of Sustainability in Higher Education. https://doi.org/10.1108/IJSHE-01-2019-0019.

Bell J.F., Wilson J.S. \& Liu G.C., 2008, Neighborhood greenness and 2-year changes in body mass index of children and youth. American Journal of Preventive Medicine 35(6): 547-553. https://doi.org/10.1016/j. amepre.2008.07.006.

Bhagwat S., Willis K., Birks H. \& Whittaker R., 2008, Agroforestry: A refuge for tropical diversity? Trends in Ecology and Evolution 23: 261-267.

Brack C.L., 2002, Pollution mitigation and carbon sequestration by an urban forest. Environmental Pollution 116(S1): 195-200.

Castaneda R.A., Doan D.D.T., Newhouse D.L., Nguyen M.C., Uematsu H. \& Azevedo J.P.W.D., 2018, A new profile of the global poor. World Development 101: 250267. https://doi.org/10.1016/j.worlddev.2017.08.002.

CGIAR, 2016, CGIAR research program on forests, trees, and agroforestry. Annual report 2016. http:// www.cifor.org/publications/pdf_files/AReports/CRP/ ARCRP2016.pdf

Chimhowu A., Hulme D. \& Munro L., 2019, The 'new' national development planning and global development goals: Processes and partnerships. World Development 120: 76-89.

Clough Y., Barkmann J., Juhrbandt J., Kessler M., Cherico T. \& Anshary A., 2011, Combining high biodiversity with high yields in tropical agroforests. PNAS 108: 8311-8316.

Ellaway A., Macintyre S. \& Bonnefoy X., 2005, Graffiti, greenery, and obesity in adults: Secondary analysis of European cross sectional survey. Bmy 331(7517): 611612. https://doi.org/10.1136/bmj.38575.664549.F7. 
Escobedo F., Varela S., Zhao M., Wagner J.E. \& Zipperer W., 2010, Analyzing the efficacy of subtropical urban forests in offsetting carbon emissions from cities. Environmental Science \& Policy 13(5): 362-372.

Fang C.F. \& Ling D.L., 2005, Guidance for noise reduction provided by tree belts Landscape and Urban Planning 71(1): 29-34.

FAO, 2016, Use of Treated Water in Forestry and Agroforestry. http://www.fao.org/sustainable-forest-management/toolbox/modules/use-of-treated-water-in-forestry-and-agroforestry/in-more-depth/en/?type=111

FAO, 2018a, Forest and sustainable cities. http://www.fao. org/3/i8707en/I8707EN.pdf

FAO, 2018b, Agroforestry. http://www.fao.org/sustainable-forest-management/toolbox/modules/agroforestry/ basic-knowledge/en/?type $=111$

FAO, 2004, Improvement of Rural Livelihoods: the role of Agroforestry. http://www.fao.org/forestry/7459-03b980 02736c1812f203700d24b933c91.pdf

FAO, 2019, Climate-smart agriculture and the Sustainable Development Goals: Mapping interlinkages, synergies and trade-offs and guidelines forintegrated implementation. FAO, Rome.

Fazio J.R., (ed.), 2010, How trees can retain stormwater runoff. Tree City USA Bulletin No. 55. Arbor Day Foundation, Nebraska City, USA.

Finlayson R., 2019, How to grow a national agroforestry policy. http://www.worldagroforestry.org/ blog/2019/09/23/how-grow-national-agroforestry-policy

Fulton B., 2013, Where is Australia headed? Some future projections. The conversation, 2013. http://theconversation.com/where-isaustralia-headed-some-future-projections- 12403

Gangadharappa N.R., Shivamurthy M. \& Ganesamoorthi S., 2003, AGROFORESTRY - A Viable Alternative for Social, Economic and Ecological Sustainability. http:// www.fao.org/3/XII/0051-B5.htm

Garrity D.P., 2004, Agroforestry and the achievement of the millennium development goals. Agroforestry Systems 61: 5-17.

Garrity D.P., Akinnifesi F.K., Ajayi O.C., Weldesemayat S.G., Mowo J.G., Kalinganire A., Larwanou M. \& Bayala J., 2010, Evergreen agriculture: A robust approach to sustainable food security in Africa. Food Security 2: 197-214.

GFRAS, 2015, Global Forum for Rural Advisory Services Strategic Framework 2016-2025. Advocacy and leadership in rural advisory services for sustainable development. Lindau, Switzerland.

Holloway J., 2012, Hot, crowded, and running out of fuel: earth of 2050 a scary place. http://arstechnica.com/science/2012/03/hotcrowded- and-running-out-of-fuelearth-of-2050-a-scaryplace
ICRAF, 2010, Agroforestry Policy Initiative. http://old. worldagroforestry.org/downloads/publications/PDFs/ RP09004.DOC

ICRAF, 2016, Agroforestry and ICRAF. http://www.worldagroforestry.org/about/agroforestry

Ilstedt U, Bargués Tobella A., Bazié H.R., Bayala J., Verbeeten E., Nyberg G., Sanou J., Benegas L., Murdiyarso D., Laudon H., Sheil D. \& Malmer A., 2016, Intermediate tree cover can maximize groundwater recharge in the seasonally dry tropics. Scientific Reports 6: 1-12.

Ilstedt U., Malmer A., Verbeeten E. \& Murdiyarso D., 2007, The effect of afforestation on water infiltration in the tropics: a systematic review and meta-analysis. Forest Ecol. Manag. 251: 45-51.

Jiang B., Larsen L., Deal B. \& Sullivan W.C., 2015, A doseresponse curve describing the relationship between tree cover density and landscape preference. Landscape and Urban Planning 139: 16-25. https://doi.org/10.1016/j. landurbplan.2015.02.

Kardan O., Gozdyra P., Misic B., Moola F., Palmer L.J., Paus T. \& Berman M.G., 2015, Neighborhood greenspace and health in a large urban center. Scientific Reports 5: 11610. https://doi.org/10.1038/srep11610.

Khera N., Metha V. \& Sabata B.C., 2009, Interrelationship of birds and habitat features in urban green spaces in Delhi, India. Urban Forestry and Urban Greening 8(3): 187-196.

Konijnendijk van den Bosch C., 2003, A decade of urban forestry in Europe. Forest Policy and Economics 5(2): 173-186.

Kumar B.M., Singh A.K. \& Dhyani S., 2012, South Asian agroforestry: Traditions, transformations, and prospects, [in:] P.K.R. Nair, D. Garrity (eds.), Agroforestry - The Future of Global Land Use. Advances in Agroforestry, vol. 9. Springer: Dordrecht, The Netherlands: 359-389. doi: 10.1007/978-94-007-4676-3_19.

Langford K., 2016, Trees shown to increase groundwater recharge. http://blog.worldagroforestry.org/index. php/2016/02/25/trees-shown-to-increase-groundwaterrecharge/

Lawrence A., De Vreese R., Johnston M., Konijnendijk van den Bosch C. \& Sanesi G., 2013, Urban forest governance: Towards a framework for comparing approaches. Urban Forestry and Urban Greening 12: 464473.

Leakey R.R., 2014, The role of trees in agroecology and sustainable agriculture in the tropics. Annual Review of Phytopathology 52: 113-133.

Leakey R.R.B., Tchoundjeu Z., Schreckenberg K., Shackleton S.E. \& Shackleton C.M., 2005, Agroforestry Tree Products (AFTPs): Targeting Poverty Reduction and Enhanced Livelihoods. International Journal of Agricultural Sustainability 3(1): 1-23. 
Lipper L., Thornton P., Campbell B.M., Baedeker T., Braimoh A., Bwalya M., Caron P., Cattanea A., Garrity D., Henry K., Hottle R., Jackson L., Jarvis A., Kossam F., Mann W., McCarthy N., Meybeck A., Neufeldt H., Remington T., Sen P.T., Sessa R., Shula R., Tibu A. \& Torquebiau E.F., 2014, Climate-smart agriculture for food security. Nature Climate Change 4(12): 10681072. http://dx.doi.org/10.1038/nclimate2437.

Maryanti M.R., Khadijah H., Muhammad Uzair A. \& Megat Mohd Ghazali M.A.R., 2016, The urban green space provision using the standards approach: issues and challenges of its implementation in Malaysia. WIT Trans. Ecol. Environ. 210: 369-379. doi: 10.2495/ SDP160311.

Mbow C., Smith P., Skole D., Duguma L. \& Bustamante M. 2014, Achieving mitigation and adaptation to climate change through sustainable agroforestry practices in Africa. Current Opinion in Environmental Sustainability 6: 8-14. doi: 10.1016/j.cosust.2013.09.002.

Mekonnen M.M. \& Hoekstra A.Y., 2016, Four billion people facing severe water scarcity. Sci. Adv., 2016, 2: e1500323.

Moigneu T., 2001, Recreation in the Paris region national forests: a priceless service which should be costless? [in:] C.C. Konijnendijk, Flemish Forest Organisation (eds.), Communicating and Financing Urban Woodlands in Europe. Proceedings of the Second and Third IUFRO European on Urban Forestry, Aarhus, Denmark, 4-6 May 1999 and Gyarmatpuszta/Budapest, Hungary, 9-12 May 2000. Ministerie van de Vlaamse Gemeenschap, Afdeling Bos \& Groen etc., Brussels: 201-206.

Montagnini F. \& Metzel R., 2017, The Contribution of Agroforestry to Sustainable Development Goal 2: End Hunger. Achieve Food Security and Improved Nutrition, and Promote Sustainable Agriculture. doi: 10.1007/978-3-319-69371-2 2.

Mooney P. \& Nicell P.L., 1992, The importance of exterior environment for Alzheimer residents: Effective care and risk management. Healthcare Management Forum 5(2): 23-29. https://doi.org/10.1016/S08404704(10)61202-1.

Morar T., Radoslav R., Spiridon L.C. \& Păcurar L., 2014, Assessing pedestrian accessibility to green space using GIS. Transylvanian Review of Administrative Sciences 10(42): 116-139.

Nair P.K.R., 1993, An introduction to agroforestry. Kluwer, Dordrecht.

Negri L.A.B., 2018, The role of scattered trees in soil water dynamics of pastures and agricultural lands in the Central American Tropics. https://pdfs.semanticscholar.org/ c90c/c8beb1202d07bb4c61ad5ce0fb9f968a5dc9.pdf

Nowak D.J., Stein S.M., Randler P.B., Greenfield E.J., Comas S.J. Carr M.A. \& Alig R.J., 2010, Sustaining
America's urban trees and forests: a Forests on the Edge report. Gen. Tech. Rep. NRS-62. United States Forest Service, Northern Research Station, Newtown Square, PA.

Prasad K., Kumar A, Dubey P. \& Mishra C.M., 2002, Significance and Use of Agro forestry system. Lab. to Land leaflet No. 10, 50 pp. (http://www.fao.org/docrep/ ARTICLE/WFC/XII/0931-B5.HTM\#P28_106), [accessed on 10th December 2019].

Pretty J.N., Morison J.I. \& Hine R.E., 2003, Reducing food poverty by increasing agricultural sustainability in developing countries. Agriculture, Ecosystems \& Environment 95: 217-234.

Pretty J. \& Bharucha Z.P., 2014, Sustainable intensification in agricultural systems. Annals of Botany 114: 15711596.

Reuters, 2018, Global temperatures on track for 3-5 degree rise by 2100: U.N. https://www.reuters.com/article/usclimate-change-un/global-temperatures-on-track-for3-5-degree-rise-by-2100-u-n-idUSKCN1NY186

Sachs J., Schmidt-Traub G., Kroll C., Lafortune G. \& Fuller G., 2019, Sustainable development report 2019. Bertelsmann Stiftung and Sustainable Development Solutions Network (SDSN), New York.

Schroth G., Fonseca G. \& Harvey C., (eds.), 2004, Agroforestry and biodiversity conservation in tropical landscapes. Island Press, Washington, DC.

Schroth G., Krauss U., Gasparotto L., Duarte Aguilar J.A. \& Vohland K., 2000, Pests and diseases in agroforestry systems of the humid tropics. Agroforestry Systems 50(3): 199-241. https://doi.org/10.1023/A:1006468103914.

SDG report, 2019, World Social Capital Monitor. http:// commons.ch/wp- content/uploads/Synopsis_SDG_Reports_Goals_Allocation_2019.pdf

Shashua-Bar L., Pearlmutter D. \& Erell E., 2009, The cooling efficiency of urban landscape strategies in a hot dry climate. Landscape and Urban Planning 92: 179-186.

Singh J.S., 2017, Environment: A futuristic view. Current Science 113(2): 25-2017. doi: 10.18520/cs/v113/ i02/210-217.

Swallow B., Boffa J-M. \& Scherr S.J., 2005, The Potential for Agroforestry to Contribute to the Conservation and Enhancement of Landscape Biodiversity, [in:] R. Mitchell, M. Grayson (eds.), World Agroforestry and the Future. World Agroforestry Centre, Nairobi, Kenya.

Tscharntke T., Clough J., Bhagwat S., Buchori D., Faust H., Hertel D., Holscher D., Juhrbandt J., Kessler M., Perfecto I., Scherber C., Schroth G., Veldkamp E. \& Wanger T.C., 2011, Multifunctional shade tree management in tropical agroforestry landscapes - A review. Journal of Applied Ecology 48(3): 619-629.

Tsioumani E., 2018, Report Shows Agroforestry's Contribution to Several SDGs. http://sdg.iisd.org/news/report-shows-agroforestrys-contribution-to-several-sdgs/ 
Turner-Skoff J. \& Cavender N., 2019, The benefits of trees for livable and sustainable communities. Plants, People, Planet. https://doi.org/10.1002/ppp3.39.

United Nations, 2016, Urbanization and Development: World Cities Report 2016. United Nations Human Settlements Programme, Nairobi. (http://wcr.unhabitat. org/main-report/).

van Noordwijk M., Duguma L.A., Dewi S., Leimona B., Catacutan D., Lusiana B., Öborn I., Hairiah K. \& Minang P.A., 2018, SDG synergy between agriculture and forestry in the food, energy, water, and income nexus: reinventing agroforestry? Current Opinion in Environmental Sustainability 34: 33-42.

Waldron A., Justicia R. \& Smith L., 2015, Making biodiversity friendly cocoa pay: Combining yield, certifi- cation, and REDD for shade management. Ecological Applications 25: 361-372.

Waldron A., Miller D.C., Redding D., Mooers A., Kuhn T.S., Nibbelink N., Roberts J.T., Tobias J.A. \& Gittleman J.L., 2017, Reductions in global biodiversity loss predicted from conservation spending. Nature 551: 364-367. doi: 10.1038/nature24295.

WCED, 1987, Our Common Future, Report of the World Commission on Environment and Development. Oxford University Press, Oxford, UK.

WHO, 2010, Urban Planning, Environment and Health: From Evidence to Policy Action. http://www.euro. who.int/_data/assets/pdf_file/0004/114448/E93987. pdf?ua $=1$ 